\title{
First report of Neopestalotiopsis clavispora causing crown rot in strawberry in Italy
}

\author{
Loredana Sigillo $^{1}$ (D) $\cdot$ Michelina Ruocco $^{2} \cdot$ Liberata Gualtieri $^{2} \cdot$ Catello Pane $^{1} \cdot$ Massimo Zaccardelli $^{1}$
}

Received: 19 July 2019 / Accepted: 12 September 2019 / Published online: 2 December 2019

(C) Società Italiana di Patologia Vegetale (S.I.Pa.V.) 2019

Keywords Fragaria $\times$ ananassa $\cdot$ Fungal disease $\cdot$ Rot collar

In October 2018, in Sele Valley (Italy), transplanted strawberry plants (Fragaria x ananassa) cv. Sabrina showed stunted starting growth. Then, a sample of 50 refrigerated plants, randomly collected from the stock, was analysed. They were externally disinfected, cut lengthwise and brown roots and crown reddish internal tissues from six plants were plated onto PDA; after two week-incubation, white and cottony fungal colonies, pale yellow on reverse side, developed, showing undulate margins and producing black acervuli, sometimes in yellow drops. Conidia were clavate $(21.3 \times 7.1 \mu \mathrm{m}$, on average), composed by one pale yellow basal cell with two appendages (13 $\mu \mathrm{m}$, on average), three central brown cells and a yaline apical cell with one appendage $(5.6 \mu \mathrm{m}$, on average); the cells were separated by transverse septa. Based on the morphology, the fungus was identified as Neopestalotiopsis sp. (Maharachchikumbura et al. 2014).

Identification was performed by amplifying and sequencing of two genetic regions ITS (ITS1, ITS4) (White et al. 1990) (GenBank accession No. MN149348) region and actin gene fragments (Triact 1, Triact 2) from two isolates. BLAST analysis showed $100 \%$ identity with Neopestalotiopsis clavispora in NCBI GenBank.

Each isolate was tested for pathogenicity on five strawberry plants by injecting five millilitres of a conidial suspension $\left(1 \times 10^{6}\right.$ spores $\left.\mathrm{mL}^{-1}\right)$ in a wound on the crown and incubated

Loredana Sigillo

loredana.sigillo@crea.gov.it

1 Consiglio per la ricerca in agricoltura e l'analisi dell'economia agraria, Centro di ricerca Orticoltura e Florovivaismo, via Cavalleggeri, 25, 84098 Pontecagnano-Faiano, Salerno, Italy

2 Istituto per la Protezione Sostenibile delle Piante, CNR-IPSP, via Università 133, 80055 Portici, Naples, Italy in growth chamber, at $25{ }^{\circ} \mathrm{C}$ and $85 \%$ humidity. After two months, reddish tissues were observed inside the collar, which resembled those on the naturally diseased plants while no symptoms were detected on water controls. The pathogen was re-isolated satisfying Koch's postulate, demonstrating that $N$. clavispora was responsible of reddish collar in strawberry as reported for the first time in Spain (Chamorro et al. 2016). To the best of our knowledge, this is the first report of $N$. clavispora causing disease on strawberry in Italy.

\section{References}

Chamorro M, Aguado A, De los Santos B (2016) First report of root and crown rot caused by Pestalotiopsis clavispora (Neopestalotiopsis clavispora) on strawberry in Spain. Plant Dis. https://doi.org/10. 1094/PDIS-11-15-1308-PDN

Maharachchikumbura SSN, Hyde KD, Groenewald JZ, Xu J, Crous PW (2014) Pestalotiopsis revisited. Stud Mycol 79:121-186

White TJ, Bruns T, Lee S, Taylor J (1990) Amplification and direct sequencing of fungal ribosomal RNA genes for phylogenetics. In: Innis MA, Gelfand DH, Sninsky JJ, White TJ (eds) PCR protocols-a guide to methods and applications. Academic Press, San Diego, pp 315-322

Publisher's note Springer Nature remains neutral with regard to jurisdictional claims in published maps and institutional affiliations. 